Ks. BOLESŁAW KUMOR

\title{
ARCHIDIECEZJA LWOWSKA OBRZĄDKU LACIŃSKIEGO W ŚWIETLE SCHEMATYZMU ARCHIDIECEZJALNEGO Z 1939 R. ${ }^{1}$
}

Miasto Lwów było jedyne w Europie rezydencją trzech metropolitów katolickich. Metropolia łacińska, wspomniana już w 1367 r. jako metropolia halicka, formalnie erygowana przez pap. Grzegorza XI bullą Debitum pastoralis officii z 13 II $1375 \mathrm{r}$. i przeniesiona do Lwowa na mocy bulli antypap. Jana XXIII In eminenti specula z 28 VIII 1412 r., byla drugą z rzędu metropolią na historycznych ziemiach polskich ${ }^{2}$. Druga metropolia katolicka we Lwowie, to metropolia obrządku ormiańskiego. Została utworzona najpóźniej w 1367 r. za zgodą króla Kazimierza Wielkiego, w 1629 r. nawiązała ścisłą łączność ze Stolicą Apostolską ${ }^{3}$. Trzecia metropolia katolicka, we Lwowie, to metropolia obrządku greckokatolickiego. Sama metropolia tego obrządku została utworzona już w 1370 r., ale w Haliczu, a następnie zanikła. Biskupstwo tego obrządku we Lwowie powstało w 1539 r., kiedy Makary Tuczapski, namiestnik halicki, zostal wyświęcony na biskupa lwowskiego, halickiego i kamienieckiego i zatwierdzony na tym urzędzie przez króla Zygmunta I Starego; on zaczął pierwszy rezydować we Lwowie. Do unii ze Stolicą Apostolską przystąpiła ta diecezja 6 VI 1700 r. ${ }^{4}$ Pap. Pius VII bullą In universalis Ecclesiae z dnia

1 Schematismus Archidioecesis Leopoliensis Ritus Latini 1939. Leopoli 1939, s. 198.

2 Vetera Monumenta Poloniae et Lithuaniae. Ed. A. Theiner. Romae 1860. Vol I, nr 964, 5. 713-714; Documenta Pontificum Romanorum Historiam Ucrainae Illustrantes. Ed. A.G. Wylykyj. Vol. I, nr 58, s. 94-96; nr 61, s. $101-103$.

${ }^{3}$ G. Pelrowicz, La Chiesa Armena in Polonia. Roma 197l, s. $18 \mathrm{nn}$.

- I. Bieńkowski, Organizacja Kościola wschodniego w Polsce. W: Kościól w Polsce. T. 2. Krakow 1969, s. 794. 
24 II 1807 r. utworzył we Lwowie metropolię tego obrządku, nadając metropolicie tytul lwowskiego i halickiego ${ }^{5}$.

Archidiecezja lwowska ob. łac. w 1770 r. objęła $30500 \mathrm{~km}^{2}, 3$ archidiakonaty (Lwów, Halicz, Żółkiew), 12 dekanatów, 39 prepozytur, 136 parafii, 168 kościołów, 40 szpitali i 25 szkół parafialnych, 61 klasztorów męskich, 12 żeńskich i około 120000 wiernych ${ }^{6}$. Ta sama archidiecezja w $1914 \mathrm{r}$. obejmowała $49444 \mathrm{~km}^{2}$ (wraz z Bukowiną), 29 dekanatów, 371 placówek duszpasterskich, 435 kaplic mszalnych, 707 kapłanów diecezjalnych, 231 zakonnych, 47 klasztorów i domów zakonnych męskich, 264 żeńskich, 134 alumnów diecezjalnych, 86 zakonnych, 186 braci zakonnych i 1054707 wiernych?. W 1939 r. archidiecezja ta obejmowała $38900 \mathrm{~km}^{2}, 28$ dekanatów, 416 parafii, 754 kapłanów diecezjalnych, 249 zakonnych, 135 alumnów diecezjalnych, 139 zakonnych, 69 klasztorów i domów zakonnych męskich i 582 zakonników, 292 klasztory i domy zakonne żeńskie i 1079108 wiernych ${ }^{8}$.

Przypatrzmy się bliżej tej archidiecezji przez pryzmat schematyzmu archidiecezjalnego z 1939 r. Arcybiskupem metropolitą był ks. Boleslaw Twardowski. Był to 38. $\mathrm{z}$ rzędu arcybiskup metropolita lwowski ob. lac. $\mathrm{z}$ rezydencją we Lwowie. Urodzony w 1864 r. i wyświęcony 1886 r., został prekonizowany na biskupa pomocniczego lwowskiego 14 IX 1918 r. przez pap. Benedykta XV. Święcenia biskupie przyjąl 12 I 1919 r. z rąk metropolity Józefa Bilczewskiego, a po jego śmierci został jego następcą, mianowany na to stanowisko 3 VIII 1923 r. przez pap. Piusa XI. Był asystentem tronu papieskiego, hrabią rzymskim, doktorem prawa kanonicznego i honorowym doktorem teologii na Uniwersytecie Jana Kazimierza we Lwowie. Zmarł 22 XI 1944 r., w przeddzień najtragiczniejszych dni dla archidiecezji. Poczet arcybiskupów lwowskich ob. łac. podaje tabela nr 1, zalączona niżej ${ }^{9}$.

5 Documenta. Vol. II, nr 871, s. 313-319.

6 J. Krętosz, Organizacja archidiecezji lwowskiej obrzqdku lacin̈skiego od XV wieku do 1772 roku. Lublin 1986, passim.

7 B. Kumor, Ustrój $i$ organizacja Kościola polskiego $w$ okresie niewoli narodowej 1772 - 1918. Kraków 1980, s. 587, 632; Schematismus Archidioecesis Leopoliensis Ritus Latini 1914. Leopoli 1914, s. 248.

8 Schematismus 1939, s. 173.

- Opracowano na podstawie: J. Krętosz, Organizacja, s. $105 \mathrm{nn}$; B. Kumor, Ustrój i organizacja, s. 272. 


\section{Tabela nr 1}

Poczet Arcybiskupów metropolitów Iwowskich obrządku łacińskiego

$$
\text { 1412-1991 }
$$

\begin{tabular}{|c|c|c|c|c|c|c|}
\hline \multirow{2}{*}{$\begin{array}{l}\text { Lp. Imię i nazwisko } \\
\text { 1. Jan Rzeszowski }\end{array}$} & Urodz. & \multicolumn{2}{|c|}{$\begin{array}{l}\mathrm{D} \text { a } \mathrm{t} \mathrm{a} \\
\text { Świẹceń } \\
\text { kapl. bpich }\end{array}$} & Arcybiskup & \multicolumn{2}{|c|}{ zmarl } \\
\hline & & & & $1412-1436$ & & 1436 \\
\hline 2. Jan Odrowąż & & & & $1437-1450$ & IX & 1450 \\
\hline 3. Grzegorz z Sanoka & & & 1451 & $1451-1477$ & $29 \mathrm{I}$ & 1477 \\
\hline 4. Jan Długosz & ok. 1415 & & 1440 & 1480 & $19 \mathrm{~V}$ & 1480 \\
\hline 5. Jan Wątróbka Strzelecki & & & & $1481-1488$ & & 1488 \\
\hline 6. Andrzej Róża Boryszewski & ok. 1435 & & & $1488-1505$ & $20 \mathrm{IV}$ & 1510 \\
\hline 7. Bernardyn Wilczek & & & & $1505-1540$ & & 1505 \\
\hline 8. Piotr Starzechowski & & & 1541 & $1540-1554$ & $1 \mathrm{IV}$ & 1554 \\
\hline 9. Feliks Ligeza & ok. 1500 & & & $1555-1560$ & $26 \mathrm{I}$ & 1560 \\
\hline 10. Paweł Tarło & & & 1561 & $1561-1565$ & $21 \mathrm{~V}$ & 1565 \\
\hline 11. Stanisław Stomowski & & & 1560 & $1565-1575$ & 22 IX & 1575 \\
\hline 12. Jan Sienieński & & & & $1576-1582$ & $\mathrm{X}$ & 1582 \\
\hline 13. Jan Dymitr Solikowski & 1539 & & & $1582-1603$ & $27 \mathrm{VI}$ & 1603 \\
\hline 14. Jan Zamojski & & & 1595 & $1604-1614$ & $3 \mathrm{IV}$ & 1614 \\
\hline 15. Jan A. Próchnicki & ok. 1553 & 1594 & 1607 & $1614-1633$ & $13 \mathrm{~V}$ & 1633 \\
\hline 16. Stanisław Grochowski & & & & 45 & I III & 1645 \\
\hline 17. Mikołaj Krosnowski & ok. 1590 & 1625 & 1641 & $1645-1653$ & $26 \mathrm{IX}$ & 1653 \\
\hline 18. Jan Tarnowski & & & & $1654-1669$ & 24 VIII & 1669 \\
\hline 19. Albert W. Koryciński & & & 1667 & $1670-1677$ & $17 \mathrm{I}$ & 1677 \\
\hline 20. Konstanty S. Lipski & ok. 1622 & & & $1681-1698$ & 14 III & 1698 \\
\hline 21. Kontanty Zieliński & ok. 1646 & 1671 & 1694 & $1700-1709$ & 17 II & 1709 \\
\hline 22. Mikołaj Popławski & 1636 & & 1685 & $1710-1711$ & 7 IX & 1711 \\
\hline 23. Jan Skarbek & 1661 & 1687 & 1696 & $1713-1733$ & $2 \mathrm{XII}$ & 1733 \\
\hline 24. Mikołaj G. Wyżycki & 1698 & 1723 & & $1737-1757$ & $7 \mathrm{IV}$ & 1757 \\
\hline 25. Mikołaj Dęboski & & & 1757 & & $23 \mathrm{XI}$ & 1755 \\
\hline 26. Władysław Lubieński & 1703 & 1727 & & $1758-1759$ & $20 \mathrm{VI}$ & 1767 \\
\hline 27. Waclaw H. Sierakowski & 1700 & 1727 & 1737 & $1760-1780$ & $25 \mathrm{X}$ & 1780 \\
\hline 28. Ferdynand O. Kicki & 1721 & 1750 & 1778 & $1780-1797$ & 2 II & 1797 \\
\hline 29. Kajetan I. Kicki & 1745 & 1769 & 1785 & $1797-1812$ & $15 \mathrm{I}$ & 1812 \\
\hline 30. Andrzej A. Ankwicz & 1777 & 1810 & 1815 & $1815-1833$ & $26 \mathrm{III}$ & 1838 \\
\hline 31. Franciszek Luschin & 1781 & 1804 & 1824 & 1834-1835 & $2 \mathrm{~V}$ & 1854 \\
\hline 32. Franciszek P. Piszte & 1786 & 1808 & 1824 & $1836-1846$ & 1 II & 1846 \\
\hline 33. Waclaw & 1787 & 1809 & & $1847-1848$ & $18 \mathrm{IX}$ & 1862 \\
\hline 34. Lukasz Baraniecki & 1798 & 1822 & 1850 & $1849-1858$ & $30 \mathrm{VI}$ & 1858 \\
\hline
\end{tabular}


Lp. Imię i nazwisko

D a $\mathrm{t} a$

Urodz. Święceń Arcybiskup zmarł kapl. bpich

35. Franciszek X. Wierzchlejski 1803

36. Seweryn T. Morawski 1819

$1826 \quad 1846 \quad 1860-1884 \quad 17$ IV 1884

37. Józef Bilczewski

1860

$1851 \quad 1881$

$2 \mathrm{~V} 1900$

38. Bolesław Twardowski

1864

1884

1901

$1884-1900$

21 III 1923

39. Eugeniusz Baziak

1890

18861919

$1900-1923$

22 XI 1944

40. Marian Jaworski

1926

19121933

$1923-1944$

1944-1962 15 VI 1962

195019841991 -

Biskupem pomocniczym we Lwowie był ks. Eugeniusz Baziak, tytularny biskup foceński. Urodził się w 1890 r. i wyświęcony w 1912 r., otrzymał nominację papieską na biskupa pomocniczego lwowskiego 15 IX 1933 r. z rąk pap. Piusa XI. Sakrę biskupią przyjął 5 XI 1933 r., a udzielił mu jej arcybiskup metropolita Twardowski. Funkcje te pełnil do śmierci metropolity Twardowskiego $(+1944)$. Urząd ten zostal utworzony w archidiecezji w 1618 r., następnie zniesiony przez zaborcze władze austriackie w 1881 r. Biskup Baziak był $\mathrm{z}$ kolei 20. biskupem pomocniczym we Lwowie ${ }^{10}$. Poczet biskupów pomocniczych lwowskich przedstawia tabela nr 2, zamieszczona niżej ${ }^{11}$.

Tabela nr 2

Poczet biskupów pomocniczych lwowskich 1618-1939

Lp. Imię i nazwisko

D a $\mathrm{t}$ a

Urodz. święceń urząd śmierci kapl. bpich

1. Tomasz Pirawski $\quad 1564$

1617-1625 30 V 1625

2. Lukasz Kaliński

$1625-1633$

3. Zachariasz Nowoszycki

1634-1641 13 III 1641

4. Andrzej Sredziński

$1641-1655$

5. Stefan Charbicki

1655-1663 20 VIII 1633

10 J. Krętosz, Organizacja, s. $103 \mathrm{n}$.

11 J. Krętosz, Organizacja, s. $102-104$; Pol. Slow. Biogr. passim, Slownik Pol. Teol. Katol. passim. 


\begin{tabular}{|c|c|c|c|c|c|}
\hline Lp. Imię i nazwisko & Urodz. & $\begin{array}{c}\mathrm{D} \text { a } \\
\text { św } \\
\text { kapl. }\end{array}$ & $\begin{array}{l}\text { a } \\
\text { ceń } \\
\text { bpich }\end{array}$ & urząd & śmierci \\
\hline 6. Jerzy Giedziński & & & & $1663-1693$ & \\
\hline 7. Jan Skarbek & 1661 & 1687 & 1696 & $1696-1713$ & 2 II 1733 \\
\hline 8. Stefan Rupniewski & 1671 & 1698 & 1713 & $1713-1716$ & 21 IV 1731 \\
\hline 9. Feliks Szaniawski & 1677 & & & $1717-1725$ & 17 XII 1733 \\
\hline 10. Hieronim Jełowicki & 1672 & & & $1725-1732$ & 8 I 1732 \\
\hline 11. Samuel Głowiński & 1703 & 1726 & & $1733-1776$ & 14 IX 1776 \\
\hline 12. Kryspin Cieszkowski & 1730 & 1758 & & $1772-1792$ & 1792 \\
\hline 13. Ferdynand Kicki & 1721 & 1750 & 1776 & $1776-1780$ & 2 II 1797 \\
\hline 14. Kajetan I. Kicki & 1745 & 1769 & 1783 & $1783-1797$ & 15 I 1812 \\
\hline 15. Seweryn T. Morawski & 1819 & 1851 & 1881 & $1881-1884$ & $2 \mathrm{~V} 1900$ \\
\hline 16. Jan książę Puzyna & 1842 & 1878 & 1886 & $1886-1894$ & 8 IX 1911 \\
\hline 17. Józef Weber & 1846 & 1873 & 1895 & $1895-1906$ & 24 III 1918 \\
\hline 18. Władysław Bandurski & 1865 & 1887 & 1906 & $1906-1918$ & 6 III 1932 \\
\hline 19. Franciszek Lisowski & 1876 & 1900 & 1928 & $1928-1933$ & 3 VI 1939 \\
\hline 20. Bolesław Twardowski & 1864 & 1886 & 1919 & $1919-1923$ & 22 XI 1944 \\
\hline 21. Eugeniusz Baziak & 1890 & 1912 & 1933 & $1933-1944$ & 15 VI 1962 \\
\hline
\end{tabular}

Kapitułę Metropolitalną we Lwowie uposażył król Władysław Jagiełło w dniu 13 XI 1429 r. Początkowo składała się z 10 kanonii gremialnych. Około 1770 r. obejmowala 7 prałatur (dziekan, prepozyt, archidiakon, kustosz, scholastyk, kanclerz, kantor) i 20 kanonii gremialnych. Reformy, redukcje i kasaty józefińskie zmniejszyły w dniu 17 VII 1787 r. Kapitułę Metropolitalną do 4 pralatów (prepozyt, dziekan, scholastyk, kustosz) i 6 kanonii gremialnych. Kapituła Metropolitalna greckokatolicka obejmowała 5 prałatów i 5 kanoników gremialnych, a Kapituła Metropolitalna ob. orm. liczyła 1 prałata (prepozyta) i 3 kanonie gremialne ${ }^{12}$.

W 1939 r. prepozytem infułatem Kapituły Metropolitalnej był ks. Józef Zajkowski, dr prawa kanonicznego, protonotariusz apostolski (ur. 1861, święc. kapł. 1883), dziekanem infułatem był ks. Henryk Badeni, dr teologii, protonotariusz apostolski, oficjal generalny i kanonik teolog (ur. 1884, święc. kapł. 1908). Kustoszem był biskup Eugeniusz Baziak, a scholastykiem ks. Kazimierz Dziurzyński, papieski pralat domowy, proboszcz parafii archikatedralnej i dziekan miasta Lwowa (ur. 1872, święc. kapł. 1896). Kolegium kanoników gremialnych stanowiło 5 kaplanow: ks. A. Warszylewicz, dr teologii i papieski prałat domowy, ks.

12 J. Krętosz, Organizacja, s. 105 nn; B. Kumor, Ustrój i organizacja, s.272. 
Ignacy Chwirut, szambelan papieski, ks. Bolesław Grudzieński, szambelan papieski, ks. Zygmunt Hałuniewicz, szambelan papieski i ks. Michał Orliński. Kanonia gremialna 6, wakowała po śmierci ks. Władysława Librewskiego, pralata kustosza ( + 3 III 1938).W Kapitule Metropolitalnej był 1 biskup, 2 infułatów, 2 prałatów papieskich i 3 szambelanów papieskich.

Kolegium kanoników honorowych, uformowane w 1787 r. przez ces. Józefa II, stanowiło 10 kapłanów: ks. Aleksander Cisło, ks. Antoni Ratuszny, ks. Stanisław Narajewski, ks. Władysław Klecan, ks. Antoni Wojnarowicz, ks. Edward Kiernik, ks. Władyslaw Matus, ks. Apolinary Wałęga, ks. Kazimierz Bilczewski. Kanonia 10, wakowala po śmierci ks. Gerarda Szmyda, proboszcza parafii św. Marii Magdaleny we Lwowie $(+11$ XII 1938). Kanonicy honorowi byli z reguły proboszczami w większych miastach (Stryj, Tarnopol, Chodorów, Dolina, Lwów, Stanisławów), lub profesorami na Wydziale Teologicznym UJK (ks. St. Narajewski).

Kuria Metropolitalna, której przewodniczył arcybiskup metropolita Bolesław Twardowski, a radę przyboczną (assessores) stanowili wszyscy członkowie Kapituły Metropolitalnej, zaś referendarzami byli wszyscy prałaci i kanonicy gremialni, a nadto 2 kanoników honorowych, oraz spoza kapituły (ks. Jan Nowicki), obejmowała Kancelarię Kurii Metropolitalnej, Sąd Arcybiskupi pierwszej i drugiej instancji i szereg wydziałów. Kancelarię prowadził kanonik kapitulny ks. Zygmunt Hałuniewicz, pomagało mu dwóch notariuszy (ks. S. Cisowski i ks. M. Kumala), 5 kancelistów i 2 kursorów.

Arcybiskupi Sąd we Lwowie stanowił pierwszą instancję dla spraw karnych i małżeńskich dla archidiecezji i równocześnie stanowił sąd apelacyjny drugiej instancji dla diecezji luckiej i przemyskiej. Sądem apelacyjnym drugiej instancji dla archidiecezji lwowskiej był Sąd Arcybiskupi w Gnieźnie. Urząd oficjała generalnego pełnił ks. infułat Henryk Badeni, a kolegium sędziów kapłanów, w tym 5 prałatów i kanoników kapitulnych, 1 kanonik honorowy i 3 dalszych kapłanów. Stanowisko jednego sędziego wakowało po śmierci ks. Władysława Librewskiego ( + 3 III 1938). Funkcję promotora sprawiedliwości i obrońcy związku małżeńskiego pełnił ks. Stanisław Narajewski, emerytowany profesor UJK, a zastępował go ks. Jan Montabetti.

Osobne kolegium stanowili w Kurii Metropolitalnej egzaminatorzy synodalni i prosynodalni, mianowani najczęściej spośród prałatów i kanoników kapitulnych i profesorów Wydziału Teologicznego UJK. Przyjmowali oni egzaminy konkursowe od kandydatów na beneficja kościelne i na posady stałych katechetów w szkołach średnich i podstawowych ${ }^{13}$. We Lwowie egzaminy te odbywały się w dniu 9 i 10 maja, oraz 3 i 4 paź-

${ }^{13}$ B. Kumor, Ustrój i organizacja, s. 222. 
dziernika. Kolegium to stanowili wszyscy prałaci i kanonicy Kapituly Metropolitalnej oraz 2 profesorów UJK (ks. St. Narajewski i ks. A. Gerstman), a także kanonik honorowy ks. E. Kiernik.

Do dalszych kolegiów i wydziałów Kurii Metropolitalnej należeli Proboszczowie konsultorzy, Archidiecezjalna Rada Administracyjna Dóbr Kościelnych, Kolegium Deputatów do Spraw Seminariów Archidiecezjalnych, Consilium a vigilantia, ustanowione $\mathrm{z}$ polecenia pap. Piusa X (1907) i kolegium cenzorów ksiąg kościelnych. Osobne i ważne miejsce zajmowała Akcja Katolicka, zorganizowana przez metropolitę B. Twardowskiego jako Archidiecezjalny Instytut Akcji Katolickiej (po 1936). Sekretarzem Instytutu był ks. Andrzej Gromadzki. Instytut dzielił się na Katolickie Stowarzyszenie Mężczyzn (sekretarzem ks. Kazimierz Gumol), Katolickie Stowarzyszenie Kobiet, Katolickie Stowarzyszenie Młodzieży Męskiej i Katolickie Stowarzyszenie Młodzieży Żeńskiej ${ }^{14}$. Zamieszczona niżej tabela $\mathrm{nr} 3$ informuje o licznie i działalności Akcji Katolickiej w archidiecezji.

\section{Tabela nr 3}

Akcja Katolicka w archidiecezji w 1939 r.

\begin{tabular}{|c|c|c|c|c|}
\hline Oddział & $\begin{array}{l}\text { Parafie } \\
\text { był }\end{array}$ & $\begin{array}{c}\text { miejskie } \\
\text { nie byl }\end{array}$ & $\begin{array}{l}\text { Parafie } \\
\text { był }\end{array}$ & $\begin{array}{l}\text { wiejskie } \\
\text { nie byl }\end{array}$ \\
\hline KSM & 130 & 117 & 54 & 155 \\
\hline KSK & 137 & 110 & 57 & 152 \\
\hline KSMM & 142 & 105 & 64 & 140 \\
\hline KSMŻ & 178 & 66 & 94 & 110 \\
\hline
\end{tabular}

Na czele Instytutu Archidiecezjalnego Akcji Katolickiej jako prezes stał Kazimierz Dzierżanowski, a jako asystent kościelny biskup Eugeniusz Baziak. Oddziałowi Katolickich Mężów przewodził Jan Tadeusz Nowakowski, sekretarzem był ks. Kazimierz Gumol, a asystentem kościelnym ks. Franciszek Janicki. Oddzialowi Katolickich Kobiet przewodniczyla Bronisława Widtowa, a sekretarzowała Ludwika Kownacka. Oddziałowi Katolickiej Młodzieży Męskiej prezesował tymczasowo Kazimierz Dzierżanowski, sekretarzował Jan Wąsowicz, a asystentem koś-

14 R. Niparko, Akcja Katolicka. W: Encyklopedia Katolicka. T. 1. Lublin 1973, k. $229-233$. 
cielnym był ks. Władysław Matus, proboszcz parafii św. Elżbiety we Lwowie. Wreszcie Oddziałowi Katolickiej Młodzieży Żeńskiej prezesowała Helena Praschil, a asystentem kościelnym był ks. Kazimierz Bilczewski, proboszcz w Stanislawowie.

Osobną instytucją w archidiecezji był Sekretariat Dobroczynności i Milosierdzia, którego sekretarzem był od 1937 r. ks. Tadeusz Fedorowicz, a także Sekretariat Generalny Apostolstwa Chorych - Radio dla chorych, prowadzony przez ks. Michała Rękasa. Wreszcie Archidiecezjalny Instytut Caritas był prowadzony przez dra O. Nadolskiego, a funkcję sekretarza przy nim pełnił ks. Tadeusz Fedorowicz. Do instytucji o charakterze kulturalnym należał Instytut Wyższej Kultury Religijnej, któremu przewodniczył ks. Jan Stepa, profesor UJK, późniejszy biskup tarnowski $(+1959)$. Instytut ten powstal $\mathrm{z}$ polecenia Stolicy Apostolskiej jako „,szkoła wiedzy religijnej w rodzaju studiów teologicznych dla katolików świeckich", a wykładowcami byli tu przeważnie profesorowie miejscowego Wydziału Teologicznego UJK ${ }^{15}$.

Otwarta uroczyście 11 XII 1759 r. jezuicka Akademia Lwowska w oparciu o dokumenty króla Jana Kazimierza (20 II 1661), króla Augusta III Sasa (19 IV 1758) i bullę pap. Klemensa XIII z 20 III 1759 r. zostala przekształcona przez cesarza Józefa II na Uniwersytet (1783), a w latach 1805-1817 na Liceum, zaś ponownie od 1817 r. jako Uniwersytet im. Jana Kazimierza we Lwowie. W szeregu polskich wyższych uczelni, po Krakowie (1364), Wilnie (1579) i Zamościu (1595), była to czwarta z rzędu wyższa uczelnia uniwersytecka ${ }^{16}$.

W 1939 r. Wydzial Teologiczny tej Uczelni obejmował 14 katedr naukowych: katedry egzegezy i nauk biblijnych Starego i Nowego Testamentu, dogmatyki specjalnej, teologii moralnej, filozofii chrześcijańskiej, teologii pastoralnej, historii Kościoła, a także katedry prawa kanonicznego i teologii fundamentalnej powstałe przed $1918 \mathrm{r}$. Na wniosek Rady Wydziału Teologicznego z 24 IV 1919 r. władze II Rzeczypospolitej zgodziły się na utworzenie 3 nowych katedr: historii sztuki kościelnej (zniesiona 1926), homiletyki i pedagogiki z katechetyką, i teologii moralnej szczególowej. W 1922 r. powstała katedra socjologii chrześcijańskiej, w 1929 r. - katedra historii Kościoła w Polsce i na Rusi ${ }^{17}$. Kolegium profesorów Wydziału Teologicznego w 1939 r. obejmowało 4 profesorów honorowych i emerytowanych, 5 profesorów zwyczajnych, 3 profesorów nadzwyczajnych, 6 docentów, 4 suplentów w tym 2 docentów oraz 2 asystentów, łącznie 24 kapłanów. Prezentuje to tabela nr 4.

15 B. Kumor, Diecezja Tarnowska. Dzieje ustroju i organizacji. Kraków 1985, s. 539.

16 Wydzial Teologiczny Uniwersytetu Jana Kazimierza we Lwowie 1918-1933. Lwów 1934 , s. $5 \mathrm{nn}$.

17 Tamże, s. $80 \mathrm{nn}$. 


\section{Tabela $\mathrm{nr} 4$}

Profesorowie, docenci i wykładowcy na Wydziale Teologicznym UJK w 1939 r. ${ }^{18}$

\section{Lp. Imię i nazwisko Urodz. Święc. Habil. Profes. Śmierci}

1. Profesorowie honorowi i emeryci

$\begin{array}{llllll}\text { 1. Stanisław Narajewski } & 1860 & 1888 & 1894 & 1899 & 1943 \\ \begin{array}{c}\text { (moralna) } \\ \text { 2. Alojzy Jougan (pastoralna) }\end{array} & 1855 & 1878 & 1901 & 1903 & 1942 \\ \text { 3. Zygmunt Bielawski (homil.) } & 1877 & 1901 & 1919 & 1920 & 1939 \\ \begin{array}{c}\text { 4. Michał Wyszyński (prawo } \\ \text { kanoniczne) }\end{array} & 1890 & 1915 & 1925 & 1930 & 1972\end{array}$

\section{Profesorowie zwyczajni}

$\begin{array}{llllll}\text { 5. Adam Gerstman (moral.) } & 1873 & 1896 & 1900 & 1907 & 1940 \\ \text { 6. Szczepan Szydelski (fundam.) } & 1872 & 1896 & 1911 & 1912 & 1967 \\ \text { 7. Piotr Stach (N. Test.) } & 1886 & 1911 & 1920 & 1921 & 1961 \\ \text { 8. Aleksy Klawek (St. Test.) } & 1890 & 1913 & 1921 & 1923 & 1969 \\ \text { 9. Józef Umiński (hist. Kościoła) } & 1888 & 1913 & 1925 & 1925 & 1954\end{array}$

\section{Profesorowie nadzwyczajni}

$\begin{array}{llllll}\text { 10. Jan Stepa (filoz.) } & 1892 & 1915 & 1929 & 1932 & 1959 \\ \text { 11. Jan Szurek (pastor.) } & 1885 & 1908 & 1923 & 1938 & 1964 \\ \text { 12. Stefan Skibniewski (filoz.) } & 1878 & 1901 & 1936 & 1938 & 1942\end{array}$

\section{Docenci}

$\begin{array}{llllll}\text { 13. Adolf Tymczak (dogm.) } & 1900 & 1924 & 1935 & & 1961 \\ \text { 14. Stanisław Frankl (fundam.) } & 1903 & 1926 & 1934 & 1938 & 1944 \\ \text { 15. Atanazy Fic OP (St. Test.) } & 1901 & 1925 & 1933 & & 1943 \\ \text { 16. Teofil Długosz (hist. Kościoła) } & 1887 & 1912 & 1937 & & 1971 \\ \text { 17. Seweryn Kowalski (N. Test.) } & 1890 & 1914 & 1938 & & 1956 \\ \text { 18. Józef Nowacki (hist. Kościoła) } & 1895 & 1917 & 1938 & & 1964\end{array}$

${ }_{18}$ Tamże, s. 104 nn; K. Lewicki, Narajewski Stanislaw. W: Pol. Slow. Biogr. T. 22 (1977), s. 524-525; J. Zieliński, Jougan Wlatyslaw Alojzy. W : Pol. Slow. Biogr. T. 11 (1964/65), s. 301; L. Grzebien, Bielawski Zygmunt.W: Pol. Slow. Pol. Teol. Katol. T. 5 (1983), s. $101-104$; L. Grzebień, Skibniewski Stefan Leon. W: Slow. Pol. Teol. Katol. T. 8 (1983), s. 335-337; Z. Mazur, Fic Atanazy Urban. W: Slow. Pol. Teol. Katol. T. 5 (1983), 


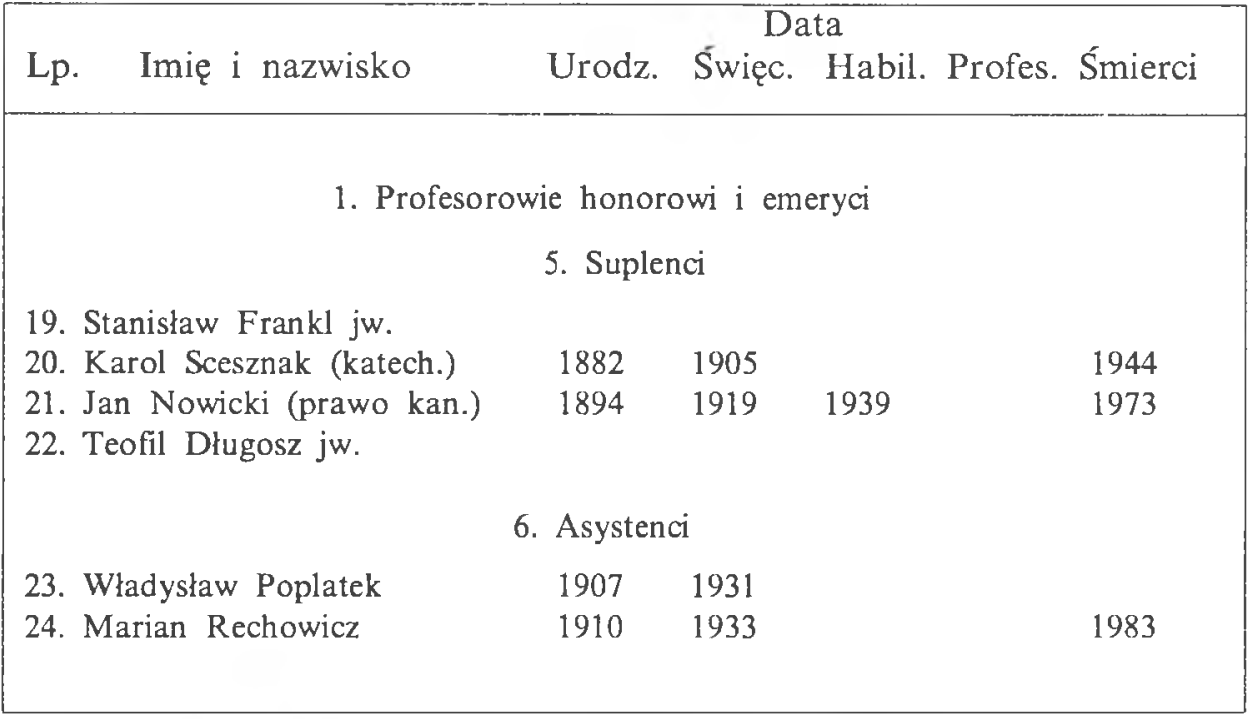

Słuchaczami Wydziału Teologicznego byli wyłącznie alumni Arcybiskupiego Seminarium Duchownego we Lwowie. Rektorem seminarium był biskup Eugeniusz Baziak, wicerektorem od 1931 r. był ks. Jan Nowicki, ojcem duchownym ks. M. Stark CM (od 1936), 4 prefektów studiów to ks. Stanisław Bizuń $(+1991)$, ks. Władysław Poplatek, ks. Marian Rechowicz $(+1938)$ i ks. Wawrzyniec Mazur. Seminarium liczyło 135 alumnów, w tym 27 na 5, $32-4,20-3,19-2$ i 37 na 1 roku studiów. Wśród tych alumnów było 3 przyszłych biskupów: ks. A. Adamiuk - biskup pomocniczy opolski (1970), ks. Ignacy Tokarczuk - biskup przemyski ob. łac. (1965) i ks. Jan Olszański - biskup kamieniecki (1991).

Archidiecezja posiadała również Małe Seminarium. Utworzył je jako pierwsze na zmiemiach polskich w 1840 r. arcybiskup metropolita Franciszek Pisztek ${ }^{19}$. Alumni Małego Seminarium uczęszczali do gimnazjum i liceum państwowego, a w seminarium otrzymywali odpowiednie wychowanie ascetyczne i kulturalne, a podlegali przełożonym Arcybiskupiego Seminarium Duchownego we Lwowie. W 1939 r. liczyło ono 14 alumnów, w tym 4 w klasie 4 . gimnazjalnej, 6 w 1 . licealnej i 4 w 2. licealnej.

W dalszej kolejności schematyzm podaje zestaw dekanatów i parafii oraz kościołów, a także funkcje i urzędy duchowieństwa zatrudnionego w duszpasterstwie. Archidiecezja w 1939 r. podzielona była na 28 dekanaów. Pierwszy raz podzielił archidiecezję na 7 dekanatów metropolita Jan

s. 368-371; K. Piętka, Frankl Stanislaw. W: Slow. Pol. Teol. Katol. T. 5 (1983), s. 405-407;

H.E. Wyczawski, Diugosz Teofll. W: Slow. Pol. Teol. Katol. T. 5 (1983), s. 302-307.

19 Kumor, Diecezja tarnowska, s. 216. 
Dymitr Solikowski na synodzie archidiecezjalnym w 1595 r. Były to dekanaty: Lwów (27 parafii), Dunajów (12 parafii), Rohatyń (12 parafii), Trembowla ( 9 parafii), Gródek Jagielloński (16 parafii), Uście-Halicz (27 parafii) i Żydaczów (24 parafie). W 1765 r. metropolita W. H. Sierakowski utworzył 5 dalszych dekanatów na skutek rozbudowy sieci parafialnej: Busk, Konkolniki, Janów, Kołomyja i Buczacz. W okresie reform józefińskich powstało 9 nowych dekanatów: Lwów - zamiejski, Brzeżany, Jazłowiec, Swierż, Bełz, Żółkiew, Brody, Stanisławów, Czerniowce, zniesiono natomiast dekanaty: Dunajów, Konkolniki, Rohatyń, Żydaczów i Janów. W 1843 r. metropolita F. Pisztek utworzył 10 nowych dekantów: Szczerzec, Stryj, Dolina, Złoczów, Gliniany, Konkolniki, Czortków, Tarnopol, Horodenka i Lubaczów. W 1875 r. metropolita F. Wierzchlejski utworzył nowy dekanat $w$ Suczawie na Bukowinie, a metropolita J. Bilczewski w 1905 r. - dekanat Skalat i Podhajce, w 1911 r. Radowce na Bukowinie ${ }^{20}$. W sumie w 1914 r. archidiecezja obejmowala 29 dekanatów. Trzy dekanaty bukowińskie (Czerniowice-Suczawa, Radowce) po 1918 r. odeszły do Rumunii, a w 1929 r. zostały włączone do diecezji Jassy. W okresie międzywojennym zostały utworzone 2 nowe dekanaty: Borszczów i Zborów. Załączona niżej tabela nr 5 prezentuje podzial archidiecezji na dekanaty w 1939 r.

\section{Tabela nr 5}

Podzial archidiecezji na dekanaty

\begin{tabular}{|c|c|c|c|c|c|}
\hline Lp. Dekanat & Dziekan & Par. & $\begin{array}{l}\text { Liczba } \\
\text { Kapl. diec. }\end{array}$ & zak. & wiernych \\
\hline 1. Lwów Miasto & K. Dziurzyński & 17 & 34 & 13 & 157470 \\
\hline 2. Lwów zamiejski & J. Wawszczak & 12 & 12 & 4 & 32235 \\
\hline 3. Bełz & J. Dymitrowski & 14 & 19 & 2 & 28527 \\
\hline 4. Borszczów & J. Machowski & 16 & 16 & 2 & 25446 \\
\hline 5. Brody & Vacat & 10 & 10 & 4 & 23616 \\
\hline 6. Brzeźany & K. Łoziński & 20 & 25 & & 47853 \\
\hline 7. Buczacz & J. Driuban & 17 & 23 & & 45314 \\
\hline 8. Busk & J. Czyrek & 11 & 15 & & 27270 \\
\hline 9. Czortków & S. Tenerowicz & 21 & 21 & 6 & 45105 \\
\hline \multirow[t]{2}{*}{ 10. Dolina } & T. Linde & 18 & 22 & & 39168 \\
\hline & & 156 & 197 & 31 & 472004 \\
\hline
\end{tabular}

20 J. Kręlosz, Organizacja, s. 171 nn.; B. Kumor, Ustrój i organizacja, s. 526, 531, 534. 


\begin{tabular}{|c|c|c|c|c|c|}
\hline Lp. Dekanat & Dziekan & Par. & $\begin{array}{l}\text { Liczba } \\
\text { Kapł. diec. }\end{array}$ & zak. & wiernych \\
\hline 11. Gliniany & J. Pękalski & 14 & 12 & 6 & 31330 \\
\hline 12. Gródek Jagiell. & P. Mikulski & 11 & 13 & & 28355 \\
\hline 13. Horodenka & L. Kościński & 13 & 11 & 4 & 26976 \\
\hline 14. Jazłowiec & S. Szkodziński & 10 & 13 & & 19497 \\
\hline 15. Kołomyja & L. Peciak & 10 & 11 & 1 & 28492 \\
\hline 16. Konkolniki & F. Wyszatycki & 15 & 16 & 2 & 26572 \\
\hline 17. Lubaczów & S. Subczyński & 13 & 15 & 2 & 38898 \\
\hline 18. Podhajce & B. Skulicz & 13 & 15 & & 26583 \\
\hline 19. Skalat & J. Ferens & 18 & 23 & & 42028 \\
\hline \multirow[t]{2}{*}{ 20. Stanisławów } & K. Bilczewski & 21 & 26 & 7 & 63195 \\
\hline & & 138 & 155 & 22 & 331920 \\
\hline 21. Stryj & A. Cisło & 18 & 13 & 9 & 36588 \\
\hline 22. Swirż & T. Blicharski & 14 & 18 & 2 & 33042 \\
\hline 23. Szczerzec & W. Cieński & 10 & 10 & 2 & 18605 \\
\hline 24. Tarnopol & A. Wałęga & 24 & 22 & 9 & 62225 \\
\hline 25. Trembowla & M. Paprocki & 21 & 28 & & 45066 \\
\hline 26. Zborów & M. Zawadecki & 11 & 14 & & 24000 \\
\hline 27. Zloczów & K. Gruszecki & 11 & 14 & 4 & 30617 \\
\hline \multirow[t]{2}{*}{ 28. Żółkiew } & I. Zmora & 13 & 16 & & 25135 \\
\hline & & 122 & 135 & 26 & 275278 \\
\hline Razem & & 416 & 487 & 79 & 1079108 \\
\hline
\end{tabular}

Pod względem liczby katolików ob. łac. największy był dekanat lwowski miejski (157 470 katolików), następnie stanisławowski (63 195) i tarnopolski (62 225), najmniejszy natomiast był dekanat szczerzecki (18 603), jazlowiecki na Podolu (19 497) i borszczowski (23 616). Co do liczby parafii pierwsze miejsce zajmowal dekanat tarnopolski (24 parafie) i na równi czortkowski (21) i stanislawowski (21), zaś najmniejszy w tym zakresie był dekanat brodzki (10) i szczerzecki (10), kołomyjski (10), a także na równi zborowski (11) i złoczowski (11), oraz buski (11) i grodecki (11). Co do liczby kapłanów pracujących w duszpasterstwie przodował dekanat Lwów Miasto (34 kapłanów diecezjalnych i 14 zakonnych), a następnie Stanisławów (26 diec. i 7 zakon.) i Tarnopol (22 diec. i 9 zakon.), dawne miasta wojewódzkie. Najmniej liczyły ich dekanaty: Szczerzec (10 diec. i 2 zakon.), Kołomyja (11 diec. i 1 zakon.) i Gródek Jagielloński (13 diec.). Przeciętnie na 1 dekanat przypadało 38540 wiernych, 14,85 parafii i 17,39 kapłanów diecezjalnych i 2,82 zakonnych. Tylko 10 dekanatów przewyższyło pod każdym względem te przeciętne szacunki dla calej archidiecezji. Osobny okręg stanowił dekanat wojskowy, na czele 
którego stal ks. prałat A. Matejkiewicz; dekanat obejmowal na terenie archidiecezji 5 parafii personalnych - wojskowych (Lwów, Stanisławów, Złoczów, Tarnopol i Stryj).

Lwów, dawna stolica Galicji, w 1939 r. stolica województwa i obok Warszawy i Krakowa glówne centrum kulturalne II Rzeczypospolitej zasługuje na specjalną uwagę. W granicach miasta było 17 parafii ob. łac., 14 kościolów zakonnych, 9 dalszych kościołów i 4 kaplice szpitalne, bardzo liczne kaplice zakonne - łącznie 32 kościoły, 4 kaplice zakonów męskich, 4 kaplice szpitalne i liczne przy domach zakonnych żeńskich. Tabela nr 6 ilustruje to zagadnienie ${ }^{21}$.

Tabela nr 6

Kościoly we Lwowie w 1939 r.

Lp. Wezwanie Parafia Liczba dusz księży zakon. diec. lub zakon.

1. Wniebowzięcia NMP

2. Boże Ciało

3. MB Śnieżna

4. Sw. Mikołaj

5. Św. Maria Magdalena

6. Św. Antoni Padewski

7. Sw. Marcin

8. Sw. Andrzej Ap.

9. Św. Anna

10. Św. Elżbieta

11. Sw. Łazarz

12. Sw. Franciszek

13. MB Różańcowa

14. MB Nieust. Pomocy

15. SS. Piotr i Pawel

16. MB Królowa Polski

17. Św. Wincentego a Paulo

18. Najśw. Serca Jezusa

19. MB. Nieust. Pomocy

20. Narodzenia NMP

\section{Bazylika}

Dominikanie

diec.

diec.

diec.

diec.

diec.

Franciszkanie

Bernardyni

diec.

diec.

diec.

Franciszkanie

Kapucyni

Misjonarze

diec.

diec.

diec.

Misjonarze

Jezuici

Karmelici bosi

Karmelici trzew.
4790

2000

5000

10000

18000

12300

12000

11000

12000

18000

200

3500

4150

7500

5077

5500

7000
16

11

21

3

3

3

$15 \quad 101$

3

4

1

4

9

2

2

2

3

3

$16 \quad 21$

$5 \quad 25$

$4 \quad 8$

21 Schematismus 1939. 


\begin{tabular}{|c|c|c|c|}
\hline Wezwanie & $\begin{array}{l}\text { Parafia } \\
\text { lub zakon. }\end{array}$ & księży & zakon. \\
\hline 21. Niepokalane Poczęcie & $\begin{array}{l}\text { Franciszkanie } \\
\text { Konwentualni }\end{array}$ & 11 & 77 \\
\hline 22. Swięta Rodzina & Reformaci & 4 & 13 \\
\hline 23. Sw. Zofia & Misjonarze & 13 & 15 \\
\hline 24. Zmartwychwstania P. Jezusa & Zmartwychwstańcy & 5 & 36 \\
\hline 25. & Redemptoryści & 3 & 4 \\
\hline 26. MB Ostrobramska & Salezjanie & 4 & 5 \\
\hline 27. MB Królowa Polski & Salezjanie & 4 & 10 \\
\hline 28. & Saletyni & 4 & \\
\hline 29. & Seminaryjny & & \\
\hline 30. Wszystkich Świętych & Bened yktynki & & \\
\hline 31. & $\begin{array}{l}\text { Franciszkanki } \\
\text { od wiecz. adoracji }\end{array}$ & & \\
\hline 32. & Karmelitanki bose & & \\
\hline
\end{tabular}

We Lwowie mieli nadto własne klasztory i domy zakonne, kościoły i kaplice: michaelici, albertyni, bracia szkolni, sercanie, oraz benedyktynki, benedyktynki od wieczystej adoracji, karmelitanki bose, franciszkanki od wiecznej adoracji, urszulanki unii rzymskiej, sercanki (Sacré Coeur), szarytki (8 domów), opatrznościanki, felicjanki, dominikanki, służebniczki starowiejskie, boromeuszki, józefitki, franciszkanki Rodziny Maryi, służebniczki dębickie, sercanki, albertynki, nazaretanki, notredamki, zmartwychwstanki, albertynki i magdalenki. Pod względem liczby kościołów i kaplic Lwów ustępował jedynie Krakowowi, a wyprzedzał Warszawę, Wilno i Poznań.

Sieć parafialna archidiecezji obejmowała 416 parafii, $242 \mathrm{z}$ nich byly nieusuwalnymi $(58,17 \%), 174$ usuwalnymi $(41,83 \%), 45$ było w administracji zakonów $(10,82 \%)$. Przeciętnie wtedy na 1 parafię przypadało 2594 wiernych i 1,36 kapłanów. Ale rzeczywistość była daleko inna. Tabela nr 7 przedstawia liczebność wiernych parafii w 1939 r.

Tabela nr 7

Liczebność wiernych w parafiach w 1939 r.

\begin{tabular}{|rrrrrr|}
\hline \multicolumn{4}{|c}{ Liczba } & parafian do & ....wiernych \\
\hline 1000 & 2000 & 5000 & 10000 & 15000 & 20000 \\
83 & 169 & 122 & 31 & 9 & 2 \\
\hline
\end{tabular}


Najwięcej parafii liczyło od 1 do 2 tysięcy wiernych $(40,63 \%)$ i od 2 do 5 tysięcy $(29,33 \%)$. Parafie liczące do 10 tysięcy wiernych stanowiły $7,45 \%$, od 10 do 15 tysięcy $2,40 \%$. Te ostatnie były głównie we Lwowie, Stanisławowie, Tarnopolu, Buczaczu, Kolomyi i Stryju. Tylko parafie św. Marii Magdaleny i św. Elżbiety liczyły 18000 wiernych i były najludniejsze w całej archidiecezji. Stosunkowo duży odsetek parafii liczył do 1 tysiąca wiernych $(19,95 \%)$. Były to najczęściej parafie wiejskie, utworzone w XX stuleciu. Najmniejsza $z$ nich, Kołodróbka, w dekanacie borszczowskim liczyła zaledwie 179 katolików ob. łac., oraz parafia św. Stanisława w dekanacie stanisławowskim, która liczyła tylko 250 katolików ob. łac. Pozostałe parafie w ogromnej większości liczyły ponad 800 wiernych. Schematyzm z 1939 r. nie informuje na temat rozległości okręgu parafialnego, chociaż czynią to schematyzmy wydawane wcześniej.

A jak przedstawiał się problem liczby kapłanów pracujących w duszpasterstwie parafialnym? Do tego typu duszpasterzy schematyzm zalicza proboszczów i wikariuszów. Katecheci pracujący na etacie państwowym nie byli wliczani do duchowieństwa parafialnego, ale stanowili osobną grupę. Tabela nr 8 ilustruje liczbę duchowieństwa pracującego w duszpasterstwie parafialnym, bez katechetów.

\section{Tabela nr 8}

Duchowieństwo pracujące w duszpasterstwie parafialnym w 1939 r.

\begin{tabular}{|c|c|c|c|c|c|c|}
\hline \multicolumn{7}{|c|}{ Liczba kaplanów pracujących w 1 parafii } \\
\hline 1 & 2 & 3 & 4 & 5 & 6 & 7 \\
\hline 263 & 109 & 35 & 6 & 2 & - & 1 \\
\hline
\end{tabular}

Zdecydowana większość parafii $(63,22 \%)$ miała tylko 1 duszpasterza - proboszcza. Byly to $z$ reguły parafie liczace do 2 tysięcy wiernych. Tylko w nielicznych wypadkach liczba wiernych przekraczała 2 tysiące osób. W 109 parafiach $(26,20 \%)$ pracowalo 2 duszpasterzy: proboszcz i wikariusz, w 35 parafiach $(8,14 \%)$ pracowalo 3 duszpasterzy - proboszcz i 2 wikariuszy. Były to $z$ reguły parafie liczące od 5 do 10 tysięcy wiernych. Tylko w 6 parafiach $(1,44 \%$ ) pracowało 4 duszpasterzy, były to z reguly parafie liczące ponad 10 tysięcy wiernych. Tylko w 2 parafiach - św. Andrzeja Apostoła i św. Elżbiety we Lwowie było po 5 duszpasterzy. 
Przewodziła wszystkim bazylika archikatedralna, gdzie kolegium wikariuszy liczyło 6 kapłanów, chociaż sama parafia miała tylko 4790 wiernych.

W archidiecezji istniały przy parafiach liczne organizacje katolików świeckich. O Akcji Katolickiej wspomniano już uprzednio. Sieć organizacyjną pozostałych instytucji przedstawia tabela $\mathrm{nr} 9$.

\section{Tabela nr 9}

Bractwa i organizacje katolików świeckich w archidiecezji w 1939 r.

\begin{tabular}{|lrr|}
\hline Lp. Organizacja & Liczba oddziałów w & parafiach \\
\hline 1. Bractwo różańcowe & 202 & $48,56 \%$ \\
2. Różaniec żywy & 293 & $70,43 \%$ \\
3. Papieskie Dzieło Rozkrzewiania Wiary & 138 & $33,17 \%$ \\
4. Trzeci Zakon św. Franciszka & 78 & $18,75 \%$ \\
5. Bractwo Najśw. Sakramentu & 62 & $14,90 \%$ \\
6. Stowarzyszenie Pań Miłosierdzia & 29 & $6,97 \%$ \\
7. Konferencja św. Wincentego a Paulo & 14 & $3,37 \%$ \\
8. Bractwo Nauki Chrześcijańskiej & 14 & $3,37 \%$ \\
9. Caritas & 7 & $1,68 \%$ \\
10. Książęco-Biskupi Komitet & 2 & $0,48 \%$ \\
11. Kasa św. Antoniego dla ubogich & 2 & $0,48 \%$ \\
12. Stowarzyszenie czynnej miłości bliźniego & 1 & $0,24 \%$ \\
13. Towarzystwo Dobroczynności & 1 & $0,24 \%$ \\
14. Krucjata Eucharystyczna & 1 & $0,24 \%$ \\
15. Stowarzyszenie Pań św. Salomei & 1 & $0,24 \%$ \\
16. Stowarzyszenie Chleb Glodnym Dzieciom & 1 & $0,24 \%$ \\
\hline
\end{tabular}

Łącznie w archidiecezji, poza Akcją Katolicką, działały 846 różne organizacje katolików świeckich w zakresie charytatywnym, dewocyjnym i społecznym. Przeciętnie tedy na 1 parafię przypadały 2,03 takie organizacje. $\mathrm{Na}$ pierwsze miejsce wysunęły się żywy różaniec i bractwo różańcowe, które działały w 495 oddziałach parafialnych. Praktycznie były one prawie w każdej parafii.

Schematyzm z 1939 r. nie podaje daty zalożenia parafii, ale czyni to schematyzm z $1932 \mathrm{r}$. To prawda, że daty te nie zawsze są pewne, zwłaszcza dotyczące okresu przedrozbiorowego. Ale w tym zakresie może nam służyć książka ks. J. Krętosza. Zagadnienie chronologii powstawania parafii $w$ archidiecezji prezentuje tabela $\mathrm{nr} 10$, załączona niżej ${ }^{22}$.

22 Schematismus Archidioecesis Leopoliensis Ritus Latini 1932. Leopoli 1932, s. 25-179; J. Krętosz, Organizacja, s. 199-203. 


\section{Tabela nr 10}

Rozwój sieci parafialnej w archidiecezji od polowy XIV w. do 1939 r.

\begin{tabular}{|rrrrrrrr|}
\hline \multicolumn{7}{|c|}{ Parafie powstale w wieku } \\
XIV & XV & XVI & XVII & XVIII & XIX & XX & Razem \\
\hline 12 & 57 & 30 & 59 & 49 & 54 & 155 & 416 \\
\hline
\end{tabular}

Rozwój sieci parafialnej przyniósł w XIV w. fundacje 12 parafii $(2,88 \%)$, w XV w. $-57(13,7 \%)$, w XVI w. $-3(7,21 \%)$, w XVII w. -59 parafii $(14,18 \%)$, w XIX w. - $54(12,98 \%)$ i w XX w. (do 1939) - 155 parafii $(37,26 \%)$. Rozbudowa sieci parafialnej w XX wieku była dzielem metropolity Józefa Bilczewskiego (107 parafii i ekspozytur) i Bolesława Twardowskiego (48 parafii i ekspozytur). Wedlug szacunku ks. Tarnawskiego za rządów arcybiskupa Bilczewskiego miało powstać 21 nowych parafii, 135 ekspozytur i 582 kaplice mszalne ${ }^{23}$.

Duchowieństwo w archidiecezji było liczne, liczyło 754 kapłanów, w tym 181 było proboszczami nieusuwalnymi, 142 proboszczami usuwalnymi, 23 administratorów, 112 wikariuszów, 185 katechetów, 98 emerytów i deficjentów, 18 profesorów, 5 docentów i asystentów na UJK, oraz 18 przebywających poza granicami archidiecezji. Pozostali pełnili inne funkcje $w$ archidiecezji. $Z$ innych natomiast diecezji pracowalo i przebywało na terenie archidiecezji 47 kaplanów. Trzeba też dodać, że 29 kaplanów zakonnych było proboszczami nieusuwalnymi, 16 usuwalnymi i 34 wikariuszami. Niektórzy katecheci byli równocześnie wikariuszami. Wśród 754 kapłanów diecezjalnych bylo 58 doktorów teologii i prawa kanonicznego oraz filozofii wraz z profesorami i docentami na UJK (7,69\%). Magistrów było stosunkowo dużo, chociaż Wydział Teologiczny nadawał ten stopień dopiero od roku akademickiego 1929/1930. Do 30 VI 1930 r. dyplomy te uzyskało 52 kapłanów ${ }^{24}$.

Mniej liczne były godności i odznaczenia rzymskie. W archidiecezji było 2 infułatów - protonotariuszy apostolskich (ks. J. Zajkowski i ks. H. Badeni), 9 papieskich prałatów domowych i 15 szambelanów papieskich. Większość księży posiadała odznaczenia diecezjalne RM (rokieta i mantolet) i exp. can. (expositorium canonicale).

23 M. Tarnawski, Arcybiskup Józef Bilczewski. Krótki rys życia i prac. Lwów 1924, s. 52.

24 Hydzial Teologiczny s. 72. 
Szczególną grupę duchowieństwa stanowili katecheci w szkolach średnich. Tylko w samym Lwowie pracowało na pełnych etatach 27 katechetów w gimnazjach, liceach zawodowych i 56 szkołach podstawowych - lącznie 99 księży katechetów. Należało do nich nauczanie młodzieży religii według zatwierdzonych programów, oraz duszpasterstwo młodzieżowe. Taką formę pracy katechetów stworzyły pod koniec XVIII wieku austriackie władze józefińskie. Działalność szkolną i duszpasterstwo katechetów lwowskich kontrolowało 12 wizytatorów $\mathrm{z}$ ramienia Kurii Metropolitalnej 25 .

Poza Lwowem, na terenie całej archidiecezji pracowało w gimnazjach i liceach ogólnokształcących 41 katechetów etatowych, w seminariach nauczycielskich 6 , w szkołach zawodowych $16 \mathrm{i}$ w szkolach podstawowych 142 katechetów. Ci ostatni - jak zauważono uprzednio - nie wszyscy byli na pełnych etatach katechety i pełnili również funkcje proboszczów i wikariuszów.

W archidiecezji 24 kapłanów przekroczyło 50 lat kapłaństwa. Najstarszy z jubilatów, ks. Józef Skwierczyński, liczył 91 lat życia, 65 lat kapłaństwa; według chronologii lat święceń do 1900 r. było wyświęconych 98 kapłanów, w okresie rządów metropolity Józefa Bilczewskiego (1900-1923) - 320 i 336 w okresie rządów metropolity Bolesława Twardowskiego. $44,56 \%$ kapłanów nie przekroczyło 16 lat kapłaństwa, czyli około 40 roku życia. Było to więc duchowieństwo w większości młode. Wszak aż 251 kapłanów nie przekroczyło 10 roku kapłaństwa (33,29\%).

Poza archidiecezją pracowało 6 kapłanów, 4 dalszych przebywało poza jej granicami, 2 kaplanów studiowalo w Rzymie, 94 pozostawało na emeryturze $(12,47 \%), 4$ było deficjentów, 12 korzystało z urlopów zdrowotnych i naukowych, a 2 nie spelniało funkcji sakralnych. Na terenie archidiecezji przebywało 47 kapłanów z innych diecezji (Poznań, Przemyśl, Kamieniec Podolski, Tarnów, Luck, Płock, Włocławek) i pracowało i w duszpasterstwie, i na uniwersytecie. Wreszcie w 1938 r. zostało wyświęconych 35 nowych kapłanów, a w tym samym roku 14 zmarło.

Życie zakonne $w$ archidiecezji, które pojawiło się tu jeszcze w XIII wieku, było bardzo rozwinięte. Wszak w $1772 \mathrm{r}$. istnialy na jej terenie 61 klasztory męskie i 710 zakonników, oraz 12 klasztorów żeńskich i 249 zakonnic ${ }^{26}$. Kasaty józefińskie w latach 1774-1795 zniosły w całej Galicji 116 , a pozostawily tylko 97 klasztorów męskich, oraz zniosly 24 i pozostawiły 12 klasztorów żeńskich ${ }^{27}$. W drugiej połowie XIX wieku, a zwłasz-

${ }^{25}$ St. Mlyczyński, Urzqd katechety zawodowego $w$ diecezji tarnowskiej. Kraków 1972 msp. 9, s. $99 \mathrm{nn}$.

26 J. Krętosz, Organizacja, s. 332.

27 P. P. Gach, Kasata zakonów na ziemiach dawnej Rzeczypospolitej i Ślqzska 1773-1914. Lublin 1984, s. 31 n. 
cza w pierwszych latach wieku XX, przed I wojną światową ze względu na szerokie wolności religijne, nastąpił żywotny rozwój życia zakonnego w archidiecezji. Rozwój ten poparł nade wszystko metropolita Józef Bilczewski, który „,chętnie witał każdy nowy dom zakonny powstający na terytorium archidiecezji, chętnie takiej osadzie duchownej czy to moralnie, czy też materialnie pomagał" ${ }^{28}$. Toteż rozwój ten był wprost imponujący. Już w 1914 r. na terenie archidiecezji działało 14 zakonów i zgromadzeń zakonnych męskich w 47 klasztorach i rezydencjach w liczbie 231 kaplanów, 86 alumnów i 186 braci zakonnych, oraz 21 zakonów i zgromadzeń żeńskich w 265 klasztorach i domach zakonnych o łącznej liczbie 1972 sióstr zakonnych ${ }^{29}$.

Ten rozwój następował nadal w XX wieku. W 1939 r. na terenie archidiecezji działało 17 zakonów i zgromadzeń zakonnych męskich, oraz 24 zakony i zgromadzenia żeńskie. Przybyły więc 3 nowe zgromadzenia męskie i 3 żeńskie. Stan zakonów w 1939 r. przedstawia tabela nr 11.

\section{Tabela nr 11}

Zakony i zgromadzenia męskie w archidiecezji w 1939 r.

Lp. Zakon

Liczba domów księży alumnów braci

1. Jezuici

2. Dominikanie

3. Karmelici trzew.

4. Karmelici bosi

5. Franciszkanie konw.

6. Bernardyni

7. Reformaci

8. Kapucyni

9. Misjonarze

10. Zmartwychwstańcy

11. Redemptoryści

12. Salezjanie

13. Saletyni

14. Michaelici

$\begin{array}{rr}6 & 46 \\ 7 & 37 \\ 4 & 10 \\ 1 & 4 \\ 7 & 26 \\ 18 & 49 \\ 2 & 6 \\ 3 & 10 \\ 5 & 24 \\ 2 & 11 \\ 1 & 3 \\ 3 & 14 \\ 2 & 7 \\ 2 & 2\end{array}$

$\begin{array}{rr} & 14 \\ 8 & 27 \\ & 13 \\ 48 & 4 \\ 70 & 30 \\ 3 & 38 \\ & 10 \\ & 9 \\ & 4 \\ & 5 \\ 9 & 1 \\ 9 & 6 \\ 1 & 4\end{array}$

28 M. Tarnawski, Arcybiskup Józef Bilczewski, s. 49.

29 Schemationus Archidioecesis Leopoliensis Ritus Latini 1914. Leopoli 1914, s. 190, 201, $244,248$. 


\begin{tabular}{|lrrrr|}
\hline Lp. Zakon & \multicolumn{5}{c|}{ Liczba } \\
& domów & księży & alumnów & braci \\
\hline 15. Bracia Szkól Chrześcijańskich & 1 & & & \\
16. Albertyni & 3 & & & 11 \\
17. Sercanie (Laicy) & 2 & & & 4 \\
Razem & 69 & 240 & 139 & 194 \\
\hline
\end{tabular}

Wzrost zatem zakonów męskich na terenie archidiecezji w stosunku do 1914 r. wynosil: 3 nowe zgromadzenia, 22 klasztory i domy zakonne męskie, 18 kapłanów, 53 alumnów i 8 braci zakonnych. Większy wzrost nastąpil wśród zakonów i zgromadzeń żeńskich. Ich stan w 1939 r. prezentuje tabela nr 12 zamieszczona niżej.

\section{Tabela nr 12}

Zakony-i zgromadzenia żeńskie w archidiecezji w 1939 r.

Lp. Zakon Liczba domów Liczba sióstr

1. Benedyktynki

2. Benedyktynki od wiecznej adoracji

3. Karmelitanki bose

4. Franciszkanki od wiecznej adoracji

5. Urszulanki unii rzymskiej

6. Sercanki (Sacré Coeur)

7. Szarytki

-8. Opatrznościanki

9. Niepokalanki

10. Felicjanki

11. Dominikanki

12. Służebniczki starowiejskie

13. Boromeuszki

14. Józefitki

15. Franciszkanki Rodziny Maryi

16. Służebniczki dębickie

17. Sercanki

18. Serafitki

19. Nazaretanki

20. Prezentki

21. Notredamki

\section{1}

1
50

45

20

35

89

49

438

75

106

232

48

368

94

1

21

54

21

4

3

2

1

6 


\begin{tabular}{|lrc|}
\hline Lp. Zakon & Liczba domów & Liczba sióstr \\
\hline 22. Zmartwychwstanki & 2 & 11 \\
23. Albertynki & 11 & 61 \\
24. Magdalenki & 1 & 3 \\
Razem & 292 & 2470 \\
\hline
\end{tabular}

W porównaniu do 1914 r. przybyły 3 nowe zgromadzenia zakonne, powstało 27 nowych domów zakonnych, a liczba sióstr wzrosla o 498 osób. Warto tu dodać, że zakony męskie prowadzily na terenie archidiecezji 2 gimnazja i 2 szkoły podstawowe, a zakony żeńskie - 6 gimnazjów i liceów, uczyły w 43 szkołach podstawowych. Siostry pracowaly nadto w 39 szpitalach i prowadzily 129 ochronek dla dzieci, 35 sierocińców, 13 burs i internatów oraz 10 domów dla nieuleczalnie chorych i dla starców. Pod ich opieką przeto pozostawały dziesiątki tysięcy ludzi chorych, sierot, małych dzieci, starców, niepełnosprawnych oraz uczącej się młodzieży.

Rok 1939 był niewątpliwie szczytowym w rozwoju archidiecezji. Okupacja archidiecezji przez Związek Radziecki i przez Niemcy hitlerowskie, a następnie włączenie prawie całej archidiecezji do Ukraińskiej Republiki Radzieckiej przyniosły jej prawdziwą, niespotykaną w dziejach katastrofę. Schematyzm z 1939 r. pozostanie trwałym pomnikiem jej świetności i pełni sił życiowych.

W II Rzeczypospolitej istnialo 6 archidiecezji ob. lac. a jakie miejsce zajmowala wśród nich archidiecezja lwowska ob. łac. pokazuje tabela $\mathrm{nr} 13^{30}$.

\section{Tabela nr 13}

Archidiecezje polskie w 1938/1939 r.

Lp. Archidiecezja Obszar Dekanaty Parafie Kapł. diec. zakon. Wierni

\begin{tabular}{|lcccrrr|}
\hline 1. Gniezno & $6200 \mathrm{~m}^{2}$ & 21 & 261 & 381 & 44 & 659210 \\
2. Kraków & 8127 & 20 & 225 & 616 & 298 & 1162840 \\
3. Poznań & 1300 & 31 & 368 & 653 & 154 & 1308278 \\
4. Warszawa & 12400 & 18 & 254 & 721 & 222 & 1638400 \\
5. Wilno & 53960 & 30 & 359 & 524 & 83 & 1162840 \\
6. Lwów & 38900 & 28 & 416 & 754 & 249 & 1079108 \\
\hline
\end{tabular}

30 B. Kumor, Granice metropolii i diecezji polskich 968-1939. Lublin 1979/71, s. 329, $332,347,377$. 
Archidiecezja lwowska była na pierwszym miejscu w Polsce co do liczby parafii, kaplanów diecezjalnych, na drugim miejscu co do terytorium i liczby kapłanów, na trzecim miejscu co do liczby dekanatów i na piątym miejscu co do liczby wiernych.

\section{Tabela nr 14}

Archidiecezje polskie w latach 1938/39

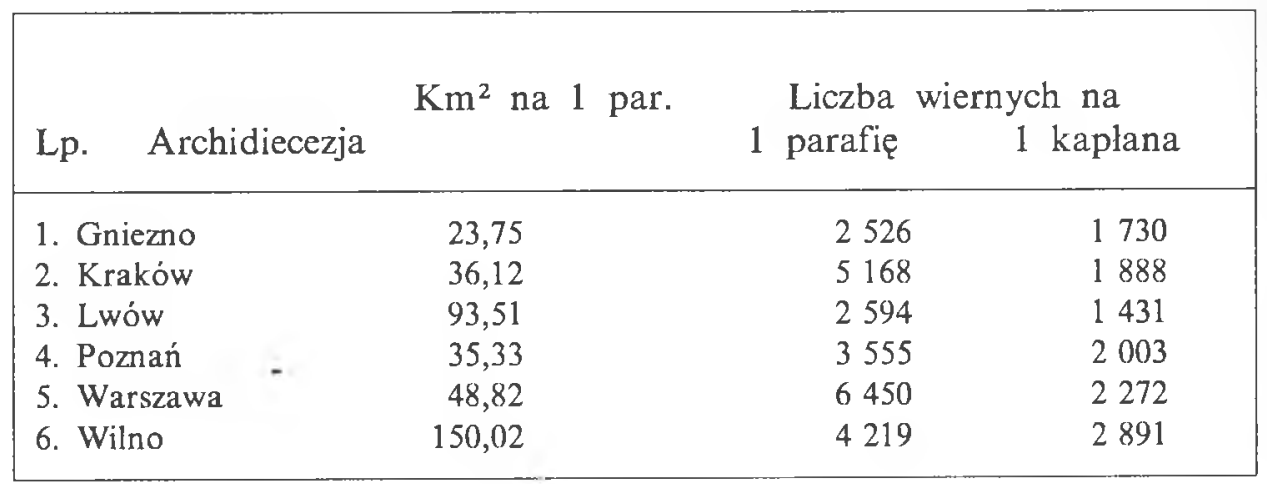

Archidiecezja lwowska zajmowała pierwsze miejsce co do liczby wiernych na 1 kapłana, drugie miejsce co do liczby wiernych na 1 parafię i piąte miejsce $w$ zakresie przeciętnego terytorium na 1 parafię. 